\title{
Interest of Learning Medical Education in FK UKI on Humaniora Medical Sciences (IHK1-IHK2)
}

\author{
Rospita Adelina Siregar
}

\author{
Fakultas Kedokteran Universitas Kristen Indonesia \\ Universitas Kristen Indonesia \\ mapituki@yahoo.co.id
}

\begin{abstract}
This study aims to classify the interest in learning of students who take part in the organization of medical education in the Medical Humanities science (IHK1-IHK2). This is based on the non-maximum learning outcomes of students in the science. The Medical Humanities Science Science (IHK1-IHK2) is taught to FKUKI semester 1 students in blocks 2-3, with learning outcomes so that students are able to become a medical profession that has introspective, ethical and professional nature. This type of research is qualitative research and the method used is a survey method with data collection techniques using a questionnaire using a Likert scale. The population of the study was 160 FKUKI students from the 2018/2019 class, which were selected into a research sample of 32 students, the sample was selected by random sampling technique. Based on 4 indicators of interest in learning consisting of feelings of pleasure, interest, attention, and student involvement in learning. From each indicator it is known that the indicators of feeling good are known to score scores 55.12; an indicator of attention with a score of 56.12; indicator of interest with a score of 50.37; and indicators of student involvement with a score of 56.25. Overall the value for students' interest in studying in the Medical Humanities science (IHK1-IHK2) is 54.47. Thus the learning interest of students in following the MK in Humanities is known to be in the medium category.
\end{abstract}

\section{Keywords: Interest in learning, Medical education, Medical humanities}

\section{INTRODUCTION}

Humanities in Latin are artes liberales which means the study of humanity, according to Ancient Greek education Humanities are called triviums namely logic, rhetoric and grammar. Humanities according to the Big Indonesian Dictionary (KBBI) Ministry of Education and Culture (Balai Pustaka: 1988) are sciences that are considered aimed at making humans more human, in the sense of making humans more civilized. Humanities are sciences that come into contact with human values that include: ethics, logic, aesthetics,Pancasila education,civic education, religion and phenomenology.

Humanities aim to advance people so as to achieve true humanity. The humanity view teaches that there is a "unity and similarity" between humans. All humans are the same, each soul is part of the fire of God. There is no difference between employers and laborers, rich and poor, male and female. All humans are brothers, because they must be love-loving (Purbakawatja and Harahap, 1982). Humanities prepare people to think flexibly, agile with all their visions and perceptions for the development and adjustment of their human values.

Schools should be a place for Humanities and manners education (Mukhtar, 2001: 5), because it must be honestly recognized that to create an atmosphere of
Humanities in schools requires school leaders who believe in the usefulness of Humanities education, can capture their core and soul, and are able to give time , cost, energy and space for activities. Sunarja (1984: 67) mentions that Humanities education is useful to always know to look at and weigh in its entirety, still respect all in its wholeness, after choosing and loving its part. With a wide range of views, open to all that is valuable from humans, even able to learn something new when necessary he does not feel inferior or super in any circumstances because as a member of society everyone must know of the failure and success of oneself in life's journey.

According to Daulay, that Humanities education is given to develop a humanitarian insight that will not be able to replace the mental and cultural land that exists in humans. Humanities education is also useful for every human being always setting aside time in managing typical human values in his life, including in this field is enjoying art, reading literature, relationships, and recreation. Humans do not allow themselves to be controlled by material calculations and work solely to achieve matter, humans also maintain balance with their spiritual aspects ( Siregar, R. A. ,2018: 280).

The Medical Undergraduate Education Program at FKUKI includes Humanities education as one of the 
minimum competencies that must be possessed, so that FKUKI students in semester 1 (one). given Humanities education material that is revealed into sciences in the form of learning blocks, this block is called the Medical Humanities (IHK) block given in IHK 1 and IHK2. In Medical Humanities (IHK 1) the material provided includes Religion, Pancasila, Citizenship and Indonesian Language, while in the Humanities Medical Science block (IHK2) students get lectures on Health Behavior Science, Medical Sociology and Medical Anthropology.

The learning process is oriented towards student center learning with a learning approach using problem solving, that is, with a mindset that brings someone to think positively to find a way out of existing problems. Then students are introduced as early as possible with health problems taken based on evidence based Medicine (EBM), through the family medicine approach, which means emphasizing family orientation in medical services, which is different from the biomedical approach (biomedical approach) and is usually disease oriented).

Each block determines learning outcomes, so that student competency can be measured systematically by fulfilling: competency areas, core competencies, and competency components. There are 7 (seven) competency areas for doctors including: effective communication, clinical skills, scientific foundation of Medical Science, Management of Health Problems, Management of Information, Self-Awareness and SelfDevelopment and Ethics, Morals, Medical and Professionalism and patient safety.

Block evaluation aims to assess whether students are able to solve health problems by raising critical thinking in themselves, independently or together, collaborating and synergizing. The block evaluation is adjusted to the level of ability expected to be achieved at the end of medical education, starting from level 1 to level 4 .

1. Ability level 1: can recognize and place clinical images according to the disease when reading the literature, at this level indicates an overview level, where if faced with patients with clinical features and suspect the disease, patients can be immediately referred

2. Ability level 2: able to make a clinical diagnosis based on physical examination and additional examinations requested by the doctor (for example a simple laboratory examination or x-ray). The doctor is able to refer the patient as soon as possible to the relevant specialist and be able to follow up afterwards.

3. Ability level 3:

3a: able to make a clinical diagnosis based on physical examination and additional examinations requested by the doctor (for example a simple laboratory examination or $\mathrm{x}$ ray). The doctor can decide and give preliminary therapy, and refer to the relevant specialist (not an emergency case).

3b: able to make a clinical diagnosis based on a physical examination and additional examinations requested by the doctor (for example a simple laboratory examination or $\mathrm{x}$ ray). The doctor can decide and give preliminary therapy, and refer to the relevant specialist (emergency case).

4. Ability level 4: able to make a clinical diagnosis based on physical examination and additional examinations requested by the doctor (for example a simple laboratory examination or $\mathrm{x}$-ray). The doctor can decide and be able to handle the problem independently until completely.

Specifically in the Medical Humanities science, block evaluations are carried out for ability level 1 . Based on the results of the block evaluation conducted on these students, the results obtained at ability level 1 still need to be improved through increasing student interest in learning.

According to Getzel (in the book Ratnawulan \& Rusdiana, 2015: 70). Interest is basically a special desire for attention. Students who are interested in a subject, and the desire for attention will be higher and their interest serves as a powerful driver to be actively involved in the teaching and learning process. Interest is implemented through active participation in an activity. To arouse students' interest in learning, each teacher should have a curiosity about why and how children learn and adapt themselves to the conditions of learning in their environment (Simatupang, 2016: 62).

The indicators of interest in learning can be interpreted as follows:

1. Feeling happy.

According to Lestari and Mokhammad (2017) happy feelings are feelings given to something that gives rise to an attitude. This happy feeling is seen by itself, where this feeling arises because of liking for example in chemistry lessons, so that without being told and without being forced students will give a feeling of love in learning chemistry. And the feeling of pleasure referred to will not feel bored in chemistry lessons, so students with happy feelings will continue to learn and not feel bored in learning chemistry lessons.

2. Interest.

According to Lestari and Mokhammad (2017) interest can arise because of the nature of an object that makes someone become interested or because of feelings of pleasure towards an object or lesson. In an interest in chemistry lessons, students will continue to try to find challenges in the contents of these lessons, and look for examples that are relevant to daily life related to chemistry lessons and will automatically discuss the chemistry subject matter.

3. Student attention.

According to Slameto (2010) attention is an activity carried out by someone in relation to the stimuli that 
come from their environment. Meanwhile, according to Soemanto attention is the concentration of soul and energy on an object that accompanies an activity. Therefore, someone who has attention to the lesson will always try hard to get the best by paying more attention to it.

4. Involvement in learning.

According to Slameto (2010) the involvement in learning referred to is one's interest in the object which causes the person to be happy and interested in doing or doing the activities of the object. Example: active in discussions, actively asking questions, and actively answering questions from educators

Based on the description above, the researcher conducted a classification of students' interest in studying following the implementation of medical education in the Medical Humanities science (IHK1IHK2). By obtaining the classification data of student learning interest, it is expected that lecturers supporting this science will be more creative in choosing learning methods based on student center learning.

\section{METHOD}

The population of this study was 160 FKUKI students from the 2018/2019 class. Samples selected This type of research is qualitative research and the method used is a survey method with data collection techniques using a questionnaire using a Likert scale. The population of the study was 160 FKUKI students from class 2018/2019, which were selected into a research sample of 32 students, the sample was selected using random sampling techniques. The research instrument used a study interest questionnaire using a Likert scale. The questionnaire consisted of 4(four) indicators of learning interest consisting of feelings of pleasure, interest, attention, and student involvement in learning. In a questionnaire that has been validated by an expert validator, each indicator is represented by 5(five) statements so that in total there are 20 statements.

\section{RESULT AND DISCUSSION}

First semester FK UKI students are given IHK 1 science with Learning outcomes. Students understand the sciences they have received, then encourage critical thinking to occur in the life phenomena in the community. Students enrich the material of religion, Pancasila and citizenship and Indonesian language, then health humanities become basic science for entry into the next level of learning.

Health behavioral material, according to Kasl and Cobb, in Sunarto 2014, can be divided into 3 (three) types of health behaviors, namely preventive health behavior (illnes behaviorrole behavior) Preventive health behavior includes self-protective behavior, basically any activity carried out by individuals who believe that they are healthy, and intend to prevent or detect disease in an asymptomatic state.

Solita Sarwono said that health behavior is any form of experience and interaction of individuals with their environment, especially concerning knowledge and attitudes about health and actions related to health and disease. Bloom said that behavior is one aspect that determines the degree of public health

Robert Kwick (1974) says that behavior is the action or action of an element of an organism that can be observed and can even be studied. Behavior is not the same as attitude, attitude is just a tendency to take action on an object, in a way that states there are signs to like or not like that object. So that for a change, behavior is influenced by factors that originate from within and outside yourself. Skiner (1938) psychological experts formulated that behavior is a person's response or reaction to external stimuli. Forms of response to stimuli are divided into closed behavior (covert behavior) and open behavior (overt behavior).

According to Max Weber, individuals take an action based on their experience, perception, understanding and interpretation of a particular stimulus object or situation can be described in accordance with Figure 1 .

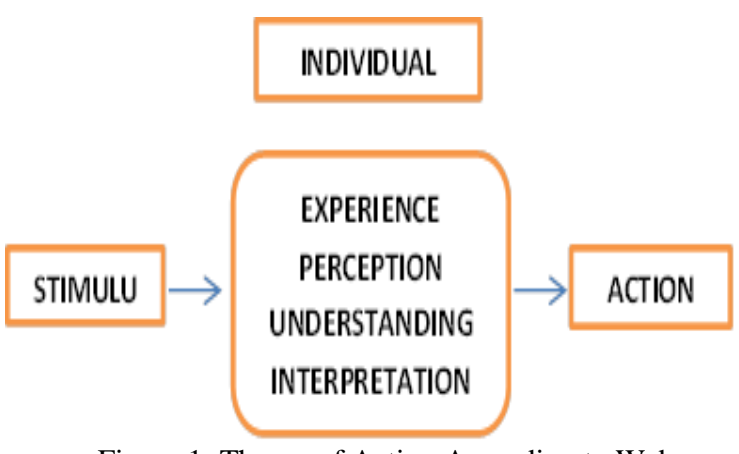

Figure 1: Theory of Action According to Weber

To build responses and actions of students in a case requires a good stimulus. One that affects the stimulus is the interest and encouragement from within yourself. That is the case in learning, so it is necessary to build student interest early on. The calcification of students interest in learning in medical humanities sciences is carried out by distributing a research instrument in the form of a learning interest questionnaire consisting of 4 indicators namely feelings of pleasure, interest, attention, and student involvement in learning. Each indicator is represented by 5 statements. The questionnaire was then distributed to 32 students who became the study sample, with the criteria that students who were the population of the study were students who were taking sciences in Medical Humanities. The questionnaire used was first validated by an expert validator. 
Classification of student learning interest can be categorized based on the range of values/scores obtained with the criteria according to table 1 .

Table 1: Learning Interest Categories Based on Value/Score

\begin{tabular}{|c|c|}
\hline Value & Category \\
\hline $70-100$ & High \\
\hline $30-70$ & Medium \\
\hline $0-30$ & Low \\
\hline
\end{tabular}

The results obtained from the distribution of the questionnaire were obtained that the classification of students' learning interest in the Humanities science was in the medium category with a score in the 30-70 category.

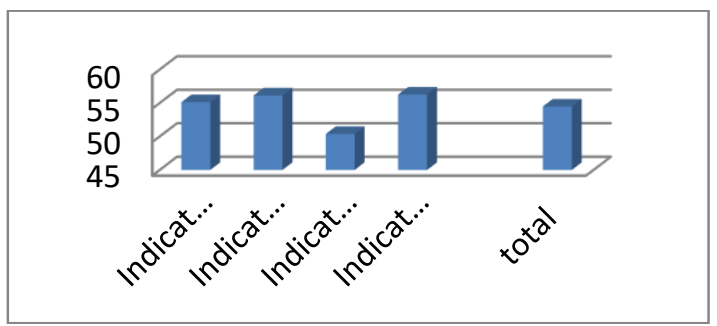

Figure 2: Average Score of FKUKI Students' Interest in Learning in the Study of Medical Humanities science

Based on the data in table 2 it is known that of the four indicators of interest in learning the classification of FK UKI students' learning interest for the Humanities science is included in the moderate category. But if seen in more detail, the highest score is on the indicator of student involvement in learning with a score of 56.25. The lowest score is on the attention indicator with a score of 50.37. Sequentially from highest to low scores for each indicator are involvement in learning, interest, feeling happy, and attention. Overall for the four indicators of interest in learning obtained score 54.47 in the medium category.
Table 2. average score obtained for each indicator of learning interest.

\begin{tabular}{|c|c|c|c|}
\hline No & Indicator & Average & Category \\
\hline 1 & Feeling happy & 55.12 & Moderate \\
\hline 2 & Attraction & 56.12 & Moderate \\
\hline 3 & Attention & 50.37 & Moderate \\
\hline 4 & Involment in learning & 56,25 & Moderate \\
\hline \multicolumn{2}{|c|}{ Average of total } & 54.47 & moderate \\
\hline
\end{tabular}

According to Tampubolon (2008) there are several things that affect interest in learning both inside and outside such as the influence of the environment, culture and relationships and teaching materials as well as the teaching methods used. Based on the data obtained, FK UKI students consist of various tribes and religions. The majority of the population is Protestant Christian (60.7\%) with 99 students, then Muslims $(23.9 \%)$ with 39 people, others with Catholic Christianity (11.6\%) with 19 people, Hindu (3\%) ) a number of 5 people and Buddha $(0.6 \%)$ a number of 1 person.

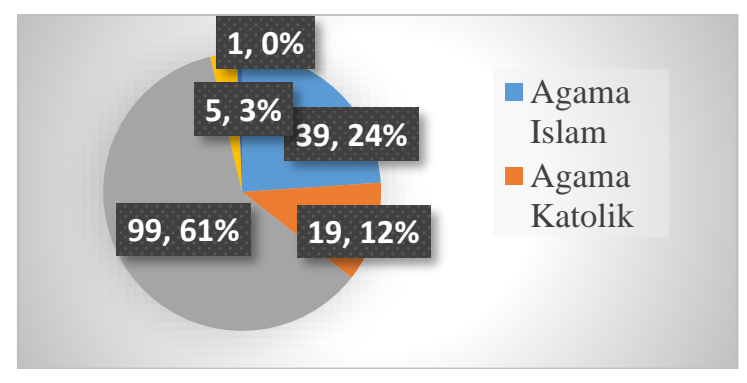

Figure 3: Type of Religion Student

Based on ethnic background, the majority of students are Batak ethnicity $(31.3 \%)$ with a total of 51 people, followed by Javanese $(17.8 \%$ ) with a total of 29 people, and there are 18 other tribes according to the detailed in

Figure

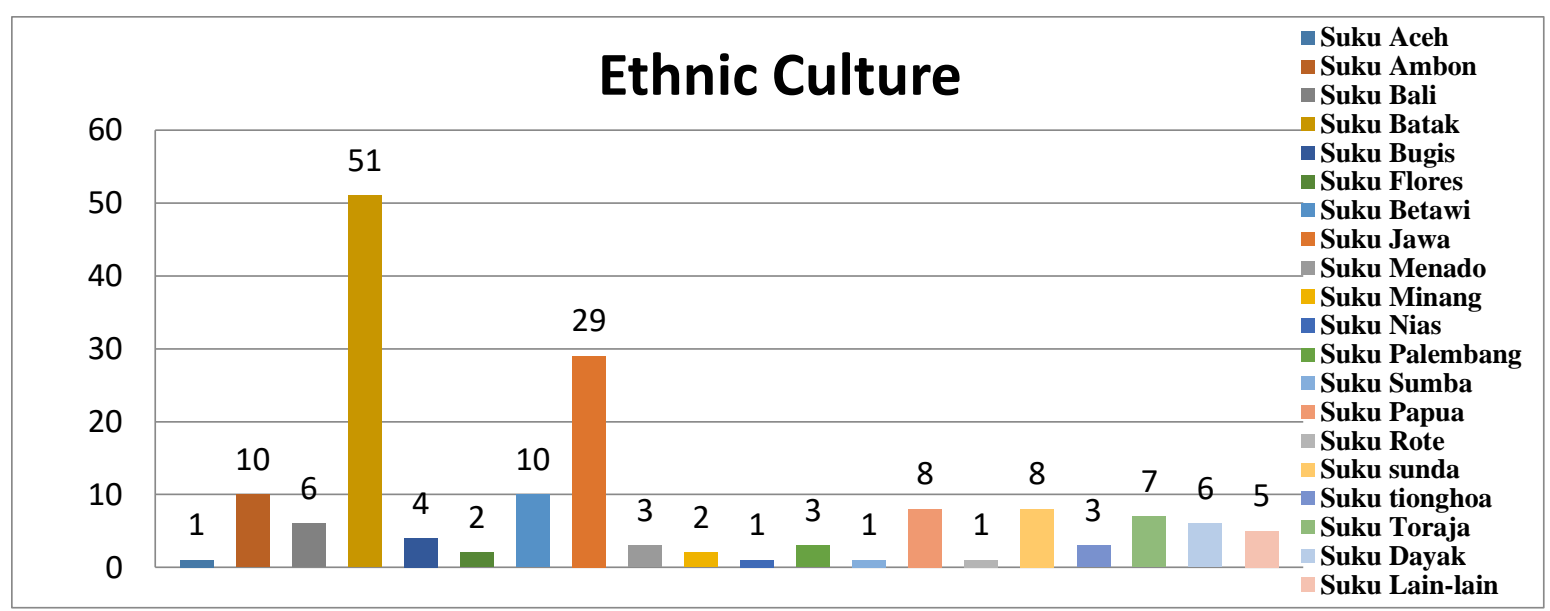

Figure 4: Type of Ethnic Culture Student 
By looking at the religious and cultural background of the students above, it can indirectly affect the students' interest in learning as conveyed by Tampubolon (2008). Therefore lecturers are expected to be able to teach creatively by using media or choosing the right teaching methods from the many learning center based learning methods offered. The selection criteria for learning methods should select learning that involves students and uses learning media that are suitable for millennial children so that in the process the level of indicators of student interest in learning in the level of involvement in learning and attention can be even higher.

\section{CONCLUSION}

The results of the study said that it is necessary to develop courses in Humanities, both IHK1 and IHK2, indicators that are judged to give results in the medium category, for feelings of pleasure, attention, interest, and involvement. Suggestion is to provide interventions in the learning process, by applying clinical skills as one of the learning methods that meets ability level 4, evaluation of blocks up to level 4 ability level. Provides education to FKUKI students about health education and behavioral science namely health behavior, medical sociology, medical and humanities anthropology according to the minimum competency that must be possessed by medical education

\section{REFERENCES}

1. Anderson, Foster. 2006, Antropologi Kesehatan. UI Press, Jakarta.
2. Departemen Kesehatan ,2004, Sistem Kesehatan Nasional, Departemen Kesehatan, Jakarta.

3. Departemen Pendidikan,2002,SK Mendiknas No.045/U/2002 Tentang Kurikulum Pendidikan Tinggi, Depdiknas, Jakarta.

4. DPK-Series 2017, Pendidikan Bioetika di bidang kedokteran dan kesehatan, MEU FK UGM,Yogyakarta.

5. Medical Anthropology Quarterly; Washington Vol. 21, Iss. 3, (Sep 2007): 249-55.

6. Konsil Kedokteran Indonesia, 2012, Standar Kompetensi Dokter, Jakarta.

7. Poerbakawatja,S.\&Harahap,A.N,1982,Ensiklopedi Pendidikan,GunungAgung, Jakarta.

8. Sarwono, S. 1993. Sosiologi Kesehatan Beberapa konsep beserta aplikasinya. Gadjah Mada University Press, Yogyakarta.

9. Simatupang, N. I. (2016). Penggunaan Media Power Point pada Model Pembelajaran Kooperatif Tipe Numbered Head Together (NHT) untuk Meningkatkan Hasil Belajar Kimia Siswa. Jurnal Pendidikan, Matematika dan Sains, 1(1), 61-72.

10. Siregar, Leonard. Antropologi dan Konsep Kesehatan, Jurnal Antropologi Papua,Volume I Agustus 2002. ISSN: 1693-2099

11. Siregar, R. A. (2018, September). Legal Protection for Consumers of Nitrogen Gas Users (Case Study of Inefficient Medical Gas). In 2018 International Conference on Energy and Mining Law (ICEML 2018). Atlantis Press.

12. Soekidjo Notoatmodjo,2007,Promosi Kesehatan dan Ilmu Perilaku, Penerbit Rineka Cipta, Jakarta.

13. Sunarto, Kamanto, 2014,Materi Pokok: Sosiologi Kesehatan,Universitas Terbuka, Jakarta.

14. Sunarja,A.SJ,1984,Memanusiakan manusia:Tinjauan Pendidikan Humaniora,BPK Gunung Mulia. Jakarta.

15. Tampubolon, D.P. (2008). Mengembangkan Minat Membaca pada Anak. Bandung: Angkasa 